3-ORIGINAL ARTICLES

\title{
Complications after bladder augmentation in children ${ }^{1}$
}

\author{
Carlos Augusto Fernandes Molina ${ }^{\mathrm{I}}$, Gilson José de Lima ${ }^{\mathrm{II}}$, Marcelo Ferreira Cassini ${ }^{\mathrm{III}}$, Murilo Ferreira de Andrade ${ }^{\mathrm{IV}}$, Inalda \\ Facincani $^{v}$, Silvio Tucci Júnior ${ }^{\mathrm{VI}}$
}

DOI: http://dx.doi.org/10.1590/S0102-86502016001300003

IPhD, Department of Surgery and Anatomy, Ribeirão Preto Medical School, University of São Paulo. Data acquisition.

IIMD, Universidade Federal do Triângulo Mineiro. Data acquisition.

IIIMD, Clinical Hospital, Ribeirão Preto Medical School, University of São Paulo. Data acquisition.

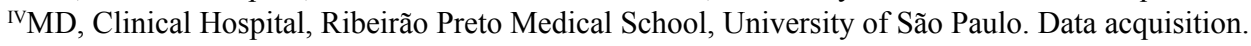

${ }^{\mathrm{v}} \mathrm{PhD}$, Assistant Professor, Clinical Hospital, Department of Puericulture and Pediatrics, Ribeirão Preto Medical School, University of São Paulo. Data acquisition.

VIPhD, Associate Professor, Head of Division of Urology, Department of Surgery and Anatomy, Ribeirão Preto Medical School, University of São Paulo. Responsible for data interpretation and writing the manuscript.

\section{ABSTRACT}

PURPOSE: Bladder augmentation is an effective surgical procedure for increasing bladder capacity and reducing pressure on the urinary system. It is indicated for patients with anomalies such as spina bifida, myelomeningocele, urethral valve and bladder exstrophy, who progress with low tolerance of medication.

CASES: This was a retrospective study conducted on pediatric patients submitted to bladder augmentation from 2000 to 2011 .

RESULTS: 34 patients aged 4 to 17 years were submitted to bladder augmentation, 30 of them with an ileal loop and 4 with a ureter.A continent urinary shunt was performed in 16 patients, the Mitrofanoff conduit was associated in 15, and the Macedo technique was used in one. Mean follow-up was 34.35 months ( 1 to 122 months). Mean creatinine was $1.5 \mathrm{ng} / \mathrm{ml}$ ( 0.4 to $7.5 \mathrm{ng} / \mathrm{ml})$ preoperatively and $1.78 \mathrm{ng} / \mathrm{ml}$ postoperatively. Three patients required a renal transplant during follow-up. There was improvement or resolution of vesicoureteral reflux in $83.5 \%$ of the kidneys on the right and in $75 \%$ on the left. Bladder capacity increased, on average, from $152.5 \mathrm{ml}$ to $410 \mathrm{ml}$. The main complications were vesical lithiasis in 3 patients and conduit perforation in one.

CONCLUSION: Bladder augmentation showed good results in this series, preserving renal function in most of the patients.

Key words: Urinary shunt. Bladder augmentation. Neurogenic bladder. Children. 


\section{Introduction}

Bladder dysfunctions, especially those associated with bladder sphincter dyssynergia, may induce structural changes in the bladder musculature such as deposition of collagen fibers and thickening of the detrusor, resulting in the reduction or loss of compliance and/or reduction of bladder capacity. These changes usually cause increased intravesical pressure and a consequent progressive deterioration of the upper urinary tract with impaired quality of life for the patient.

An early diagnosis of bladder dysfunctions and the introduction of treatment before the onset of symptoms prevent or minimize the damage to the bladder and to the upper urinary tract. The diagnosis is based on clinical suspicion and on physical examination associated with imaging exams for the evaluation of the urinary tract. Uretrocystography and ultrasonography are used to evaluate renal morphology, detrusor thickness, bladder format and capacity, presence of pseudodiverticula, vesicoureteral reflux (VUR), and postmictional residue. A urodynamic study permits the evaluation of bladder compliance and capacity, intravesical pressure and the presence or absence of bladder sphincter dyssynergia and bladder hyperactivity.

The treatment of neurogenic bladder dysfunction may be clinical or surgical and its objective is to increase bladder capacity and compliance and to reduce intravesical pressure. Clinical treatment is based on the use of anticholinergic drugs and the introduction of clean intermittent catheterization. If the patient shows low tolerance to the medication or if medication fails, as observed in 10 to $15 \%$ of the patients ${ }^{1}$, surgical treatment is instituted, basically consisting of the application of botulin toxin to the detrusor or of surgical augmentation of bladder capacity, usually employing an ileal segment, always with the objective of increasing bladder capacity and compliance.

In the present study we report the results obtained with bladder augmentation in children with bladder dysfunction.

\section{Patient series}

The medical data of 34 pediatric patients submitted to bladder augmentation in a university institution from 2000 to 2011 were retrospectively analyzed.

\section{Results}

Thirty children ranging in age from 4 to 17 years (mean: 10.3 years), 17 boys and 17 girls, were submitted to bladder augmentation. Mean follow-up was 34.35 months (range: 4 to 122 months).

Surgical indication was due to the persistency of low bladder compliance and capacity, with myelomeningocele being the most frequent etiologic factor (Table 1).

TABLE 1. Relationship between the cases (n) and the etiology of low compliance.

\begin{tabular}{cc}
\hline (n) Children & Etiology \\
\hline $\mathbf{2 2}$ & Neurogenic Bladder (15 Myelomeningoceles) \\
$\mathbf{0 4}$ & Anorectal Anomaly \\
$\mathbf{0 3}$ & Posterior Urethral Valve \\
$\mathbf{0 2}$ & Low Capacity Bladder (idiopathic) \\
$\mathbf{0 1}$ & Refractory Incontinent Epispadias \\
$\mathbf{0 1}$ & Caudal Regression Syndrome \\
$\mathbf{0 1}$ & Severe Urethral Stenosis \\
Total $=\mathbf{3 4}$ & \\
\hline
\end{tabular}

*(17 boys and 17 girls)

An ileal segment with an average length of $19.3 \mathrm{~cm}$ (range: 10 to $30 \mathrm{~cm}$ ) was used in 30 patients and a ureter in the remaining four. Eleven patients maintained a vesicostomy previously performed as part of treatment, which was closed during the bladder augmentation procedure.

A continent urinary shunt was performed in 16 patients, consisting of a Mitrofanoff conduit ${ }^{2}$ in 15 and with the use of the Macedo technique ${ }^{3}$ in one. Closure of the bladder neck was performed in 7 of these patients. General surgical time ranged from 125 to 480 minutes (mean: 255.3 minutes).

Creatinine ranged from 0.4 to $7.5 \mathrm{mg} / \mathrm{dl}$ (mean: $1.5 \mathrm{ng} /$ $\mathrm{ml}$ ) preoperatively and from 0.1 to $9.7 \mathrm{ng} / \mathrm{ml}$ (mean: $1.78 \mathrm{ng} / \mathrm{ml}$ ) postoperatively, with stable or improved levels in 20 patients and worsened levels in 9.

Three patients were submitted to renal transplantation during follow-up (pre-augmentation serum creatinine of 7.5, 2.6 and $7.1 \mathrm{mg} / \mathrm{dl}$, respectively). The cause of renal failure was neurogenic bladder in two and posterior urethral valve in one. Serum urea varied on average from $44.4 \mathrm{mg} / \mathrm{dl}$ preoperatively to $45.2 \mathrm{mg} / \mathrm{dl}$ postoperatively. One female patient is currently on hemodialysis (pre-augmentation creatinine $1.9 \mathrm{mg} / \mathrm{dl}$ ) and a male patient continues to be on hemodialysis that was initiated before augmentation due to end-stage chronic renal failure consequent to a posterior urethral valve.

VUR was present in 19 kidneys before bladder augmentation, on the right in 7 cases and on the left in 12 . No 
patient was submitted to ureteral reimplantation. Postoperative evaluation revealed improvement in 9 kidneys, worsening in 2, and stability in one.

Of the 15 patients submitted to bladder augmentation and to a conduit for catheterization by the Mitrofanoff technique, 7 are continent and 8 have small urine losses in the intervals between catheterizations. The patient submitted to the Macedo procedure is continent. Two thirds of the patients who were not submitted to conduits for catheterization are continent (10 continent and 5 incontinent).

In the urodynamic study preceding augmentation, maximum cystometric capacity ranged from 50 to $360 \mathrm{ml}$ (mean: $145.62 \mathrm{ml}$ ). In the postoperative evaluation, mean cystometric capacity was $410 \mathrm{ml}(200-550 \mathrm{ml})$.

Perforation of the conduit for catheterization (Mitrofanoff) occurred in one patient. After surgical correction, the patients perform catheterization without difficulty. A bladder calculus was detected in 4 patients. No patient developed bladder cancer during follow-up and none had water-electrolyte disorders. One female patient died of an unknown cause.

\section{Discussion}

One of the most serious problems faced by patients with bladder dysfunction is the possibility of progressive functional loss of the kidney, usually secondary to the changes in the dynamics of the lower urinary tract and more specifically due to reduced bladder compliance and capacity and elevated intravesical pressure associated with urinary infections. An early diagnosis and treatment of this situation is the responsibility of the attending physician. Pediatricians and pediatric urologists must work together to prevent the progression of dysfunction to chronic renal insufficiency in children.

Bladder dysfunctions are classified as being of neuropathic and non-neuropathic origin. The latter refers to patients in whom a neurologic injury is not clearly identified and bladder dysfunction can even be transitory. Among the neuropathic conditions, myelodysplasia and dysraphism represent the most common causes of bladder dysfunction in children, including myelomeningocele, lipomyelomeningocele and sacral agenesis, among others. Obstructive processes of the lower urinary tract such as posterior urethral valve and anomalies of bladder and perineal muscle development such as bladder extrophy and epispadias may cause some degree of bladder dysfunction during treatment ${ }^{4}$.

As mentioned earlier, unsuccessful treatment with anticholinergic agents and clean intermittent catheterization imply the indication of botulin toxin application to the detrusor or bladder augmentation ${ }^{5}$.

Botulin toxin has been used in various diseases of the urinary tract such as idiopathic or neurogenic detrusor hyperactivity, interstitial cystitis, painful bladder syndrome and benign prostatic hyperplasia ${ }^{6}$. Reports of the application of botulin toxin to children have shown good results. Hoebeke et al. ${ }^{7}$ achieved improvement of detrusor hyperactivity in $70 \%$ of 21 patients after a single application. However, they also reported side effects in all children studied $^{7}$. In a retrospective analysis of 10 children with detrusor hyperactivity of neurogenic cause treated with 3 to 5 applications of botulin toxin, Schulte-Baukloh et al. ${ }^{8}$ reported improvement of urodynamic parameters ${ }^{8}$. In a previous study, these investigators emphasized the need for periodical reapplications of botulin toxin to the detrusor'.

Bladder augmentation is believed to improve the quality of life of children or adolescents with urinary incontinence ${ }^{10}$. The closure of the bladder neck performed during ileocystoplasty is effective for the control of urinary incontinence. This procedure involves low morbidity, at times requiring surgical revision, but its indication requires adhesion to the process of intermittent catheterization $^{11}$

The tissue considered to be ideal for augmentation is the urinary tract itself, used in situations of unilateral renal exclusion with ureteral dilatation ${ }^{12,13}$. When it is not possible to use the ureter, intestinal segments of the colon or ileum are usually employed or, more rarely, a gastric segment is used. However, due to the complications related to the use of intestinal tissue in the urinary tract, there is a need to search for alternative tissues for bladder augmentation.

Bladder augmentation with an intestinal segment is not free of complications. These complications may be related to the procedure itself such as difficulty in conduit catheterization, urinary infections, intestinal obstruction or anastomosis dehiscence, lithiasis or perforation of the reservoir and neoplasias, as reported by DeFoor et al. ${ }^{14}$ in the evaluation of 26 children $^{14}$. In addition, these patients present metabolic and electrolytic intercurrences after incorporation of the intestinal segment to the urinary tract, with metabolic acidosis being the most common ${ }^{14-17}$.

Chronic acidosis can cause a reduction of bone mineral density and rickets or osteomalacia in children and osteoporosis in adults ${ }^{5}$. However, even though some authors consider that children who require bladder augmentation are at a higher risk for osteopenia and compression fractures, the risk factors are often associated more with the base disease of the patient than with the surgical procedure ${ }^{18}$. 
Another possible complication is deficiency of vitamin $\mathrm{B}$, which is absorbed through the ileum. In cases in which an ileal segment is used for bladder augmentation, the deficiency of this vitamin may cause megaloblastic anemia and Hunter glossitis. It has been reported that up to $35 \%$ of patients submitted to bladder augmentation with ileal tissue will require B12 replacement.

The intestinal changes that occur are mainly related to the enterohepatic circulation of bile salts and to colonization of the ileum by colonic bacteria in cases in which the ileocecal valve was removed. Increased concentrations of bile salts, water and sodium in the colon may cause diarrhea and steatorrhea. Colonization of the ileum by colonic bacteria alters the conjugation of bile salts, reducing fat absorption and also contributing to steatorrhea. The absorption of insoluble vitamins (A, D, K) may be impaired.

During the follow-up of the present patients, none of them presented clinical manifestations of water-electrolyte disorders and none required replacement of vitamin B12 or of liposoluble vitamins. This was probably due to the fact that the terminal ileum and the ileocecal valve were preserved, preventing diarrhea and preserving vitamin B12 absorption. No patient had osteomalacia or rickets.

Regarding the complications related to the conduit for bladder catheterization, such as stenosis of the stoma, incontinence, difficulty in performing catheterization, prolapse, bleeding and perforation, reintervention is usually necessary for correction. In the present study, only one patient had perforation of the conduit, which was corrected with surgery.

Bladder lithiasis is another known complication that can occur in $23 \%$ of patients with bladder augmentation, especially when a colon segment is used ${ }^{17}$. In an attempt to reduce the incidence of lithiasis, which may require a surgical procedure for calculus removal and may be associated with urinary infection, periodic bladder washing with $50 \mathrm{ml}$ of saline solution two to four times a day is recommended. The intestinal segment used for augmentation may produce large amounts of mucus which facilitate the obstruction of the bladder outlet and the formation of calculi ${ }^{19,20}$. A technical step that may be of help in reducing the incidence of lithiasis is the site of conduit implantation (Mitrofanoff) for catheterization. Patients with an implant in the posterior bladder wall, which perhaps permits a more effective drainage of urine and mucus, develop fewer calculi than patients with an implant in the anterior bladder wall ${ }^{21}$. In the patients of the present series the incidence of bladder lithiasis was $11.7 \%$, corresponding to 4 cases treated by percutaneous cystolithotomy.

The management of VUR in bladder augmentation is a controversial point, with some authors suggesting ureteral reimplantation at the time of augmentation ${ }^{22}$ while others believe in the reduction of VUR degree or in VUR disappearance with a reduction of intravesical pressure ${ }^{23,24}$. In a more recent review study, Misseri et al. ${ }^{25}$ reported that the option not to reimplant the ureters is more frequent among patients with low grade VUR, especially the unilateral form. However, they stated that they did not detect a clear correlation between degree of reflux and successful reimplantation. Based on their review, they were unable to conclude whether ureteral reimplantation was more successful than observation, or vice versa.

Ureteral reimplantation was not performed in any of the present patients with VUR. Nine of the 19 kidneys with VUR showed improvement. However, since urethrocystography was not available for all patients, it is difficult to reach a definitive conclusion regarding our patients.

\section{Conclusion}

Bladder augmentation with an ileal segment in children is a procedure that can provide good results in terms of preservation of the upper urinary tract and of renal function, permitting some previously incontinent patient to achieve continence. Clinical and surgical complications can occur considering the complexity of the base disease, the clinical condition of the patient, the results of previous treatments, and the magnitude of the surgical procedure. Thus, these children require long-term follow-up and their attending physicians, pediatrician and urologist, must be able to recognize these complications and how to treat them.

\section{References}

1. Gamé X, Mouracade $P$, Chartier-Kastler E, Viehweger E, Moog R, Amarenco G, Denys P, De Seze M, Haab F,Karsenty G, Kerdraon J, Perrouin-Verbe B, Ruffion A, Soler JM, Saussine C. Botulinum toxin-A (Botox $\left.{ }^{\circledR}\right)$ intradetrusor injections in children with neurogenic detrusor overactivity/neurogenic overactivity bladder: A systematic literature review. J Pediatr Urol. 2009; 5(3):156-64. PMID: 19264554.

2. Mitrofanoff P. Trans-appendicular continent cystostomy in the manangement of the neurogenic bladder. Chir Pediatr. 1980;21(4):297-305. PMID: 7408090.

3. Macedo A Jr, Srougi M. A continent catheterizable ileum-based reservoir. BJU Int. 2000;Jan;85(1):160-62. PMID:10619966.

4. Yeung CK, Barker GM, Läckgren G. Pathophysiology of bladder dysfunction. Ch 27, 353-365. In. Pediatric Urology. Ed. Gearhart JP, Rink RC, Mouriquand PDE. Saunders Elsevier, 2010.

5. Romero RM, Rivas S, Parente A, Fanjul M, Angulo JM. Injection of botulinum toxin (BTX-A) in children with bladder dysfunction due to detrusor overactivity. Actas Urol Esp. 2011; 35(2):89-92. PMID: 21256633.

6. Yokoyama T, Chancellor MB, Oguma K, Yamamoto Y, Suzuki T, Kumon H, Nagai A. Botulinum toxin type A for the treatment 
of lower urinary tract disorders. Int J Urol. 2012; 19(3):202-15. PMID:22220916.

7. Hoebeke P, De Caestecker K, Vande Walle J, Dehoorne J, Raes A, Verleyen P, Van Laecke E. The effect of botulinum-A toxin in incontinent children with therapy resistant overactive detrusor. J Urol. 2006; 176(7):328-31. PMID: 16753434.

8. Schulte-Baukloh H, Knispel HH, Stolze T, Weiss C, Michael $\mathrm{T}$, Miller K. Repeated botulinum-A injections in treatment of children with neurogenic detrusor overactivity. Urology. 2005 Oct; 66(4):865-70. PMID: 16230156.

9. Schulte-Baukloh H, Michael T, Stürzebecher B, Knispel HH. Botulinum-A toxin detrusor injection as a novel approach in the treatment of bladder spasticity in children with neurogenic bladder. Eur Urol. 2003 Jul; 44(1):139-43. PMID: 12814690.

10. Vajda P, Kispal Z, Lenart I, Farkas A, Vastyan AM, Pinter AB. Quality of life: urinary bladder augmentation or substitution in children. Pediatr Surg Int. 2009 Feb; 25(2):195-201. PMID: 19130061.

11. Landau EH, Gofrit ON, Pode D, Jurim O, Shenfeld OZ, Duvdevani M, Gross EM, Merguerian PA, Katz R. Bladder neck closure in children: a decade of followup. J Urol. 2009 Oct; 182(4):1797-801. PMID: 19692069.

12. Husmann DA, Snodgrass WT, Koyle MA, Furness PD 3rd, Kropp BP, Cheng EY, Kaplan WE, Kramer SA. Ureterocystoplasty: indications for a successful augmentation. J Urol. 2004 Jan; 171(1): 376-80. PMID: 14665935.

13. Youssif M, Badawy H, Saad A, Hanno A, Mokhless I. Augmentation ureterocystoplasty in boys with valve bladder syndrome. J Pediatr Urol. 2007 Dec;3(6):433-37. PMID: 18947790.

14. DeFoor WR, Heshmat S, Min evich E, Reddy P, Koyle M, Sheldon C. Long-term outcomes of the neobladder in pediatric continent urinary reconstruction. J Urol.2009 Jun;181(6):2689-93. PMID: 19375740.

15. López Pereira P, Valle JAM, Espinosa L, Dorrego JMA, Lucena LB, Urrutia MJM, Romera RL, Picazo ML, Viguer JM, Monereo EJ. Enterocystoplasty in children with neuropathic bladders: long-term follow-up. J Pediatr Urol. 2008 Feb; 4(1):27-31. PMID: 18631888.

16. Austin JC. Long-term risks of bladder augmentation in pediatric patients. Curr Opin Urol. 2008 Jul;18(4):408-12. PMID: 18520764

17. Kispal Z, Balogh D, Erdei O, Kehl D, Juhasz Z, Vastyan AM, Farkas A, Pin ter AB, Vajda P. Complications after bladder augmentation or substitution in children: a prospective study of 86 patients. BJU Int. 2011 Jul; 108(2):282-89. PMID:21070584.

18. Taskinen S, Fagerholm R, Mäkitie O. Skeletal health after intestinal bladder augmentation: findings in 54 patients. BJU Int. 2007 Oct;100(4):906-10. PMID: 17662076.
19. Van den Heijkant M, Haider N, Taylor C, Subramaniam R. Efficacy of bladder irrigation and surveillance program in prevention of urinary tract infections and bladder calculi in children with an ileocystoplasty and bladder neck repair. Pediatr Surg Int. $2011 \mathrm{Jul}$; 27(7):781-5. PMID: 21553274.

20. Khoury AE, Salomon M, Doche R, Soboh F, Ackerley C, Jayanthi R, McLorie GA, Mittelman MW. Stone formations after augmentation cystoplasty: the role of intestinal mucus. J Urol. 1997 Sep;158(3):1133-7. PMID: 9258156.

21. Berkowitz J, North AC, Tripp R, Gearhart JP, Lakshmanan Y. Mitrofanoff continent catheterizable conduits: Top down or bottom up? J Pediatr Urol. 2009 Apr;5(2):122-5. PMID: 19083271.

22. Soygur T, Burgu B, Zümrütbas A, Süer E. The need for ureteric reimplantation during augmentation cystoplasty: video-urodynamic evaluation. BJU In t. 2010 Feb; 105(4):530-2. PMID: 19583716.

23. Nasrallah PF, Aliabadi HA. Bladder augmentation in patients with neurogenic bladder and vesicoureteral reflux. J Urol. 1991 Aug; 146(2):563-6. PMID:1861301.

24. López Pereira P, Urrutia MJM, Romera RL, Jaurequizar E. Should we treat vesicoureteral reflux in patients who simultaneously undergo bladder augmentation for neuropathic bladder? J Urol. 2001 Jun; 165(6):2259-61. PMID: 11371958.

25. Misseri R, Rosenbaum DH, Rin k RC. Reflux in cystoplasties. Arc Esp Urol. 2008 Mar; 61(2):213-17.

\section{Correspondence:}

Prof. Dr. Silvio Tucci Junior

Av. Bandeirantes, 3900 - Campus Universitário - Monte Alegre - $9^{\circ}$ andar 14048-900 - Ribeirão Preto, São Paulo, Brasil

Tel.: (55 16) 3602-2453

stucci49@gmail.com

\section{Conflict of interest: none}

Financial source: Division of Urology, Department of Surgery and Anatomy, Faculty of Medicine of Ribeirão Preto, University of São Paulo.

${ }^{1}$ Research performed at Department of Surgery and Anatomy and in the Department of Puericulture and Pediatrics, Ribeirão Preto Medical School, University of São Paulo, Ribeirao Preto-SP, Brazil. 